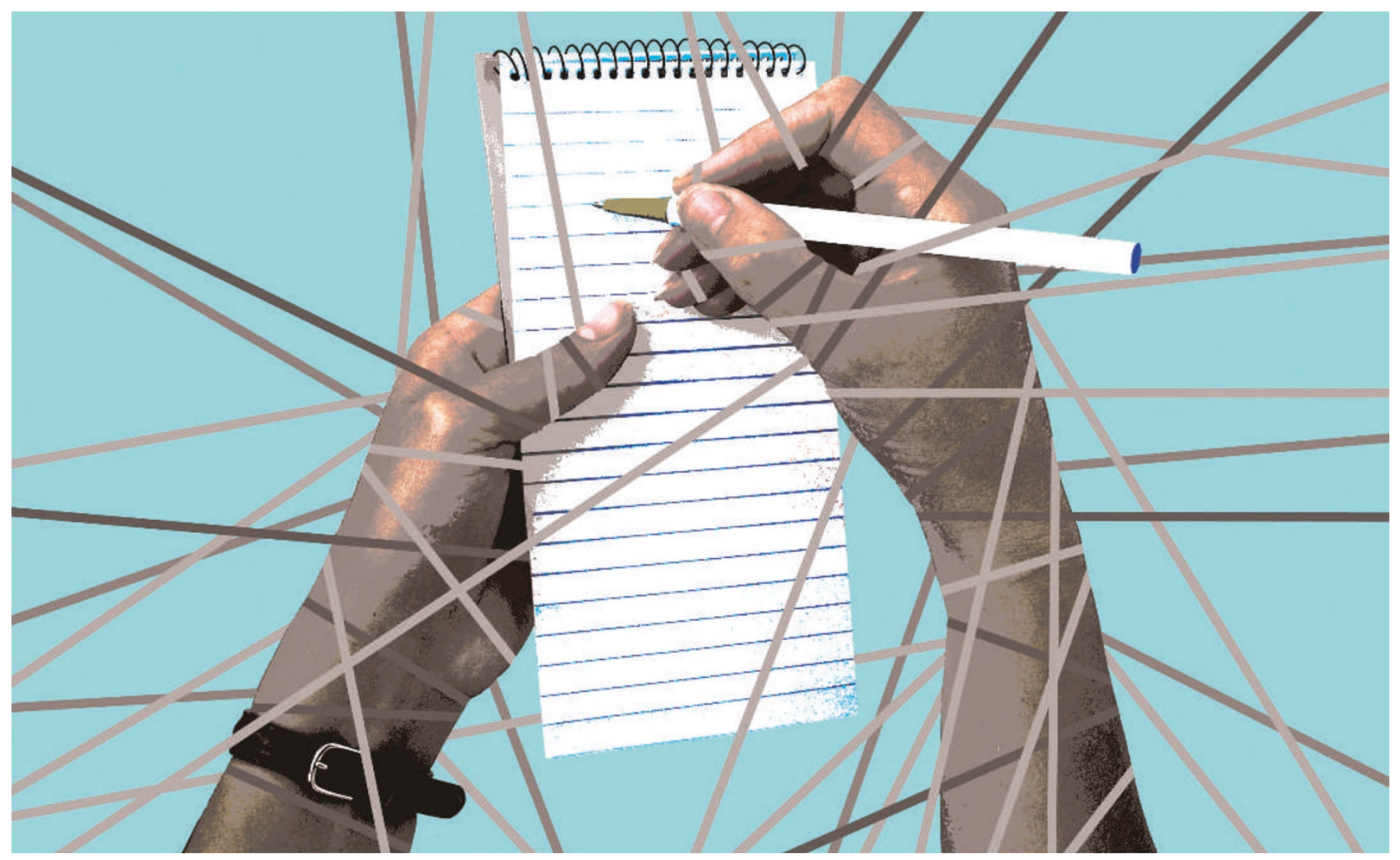

\title{
Fighting a reporting battle
}

\section{Science journalists in the developing world face unique stumbling blocks, even as some of the biggest science stories unfold around them. Mike Shanahan reports.}

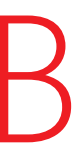

ennen Buma Gana, a freelance science journalist in Yaoundé, Cameroon, says he often learns about discoveries in his country from media outlets thousands of miles away. "African scientists are unknown at home," says Buma Gana, who has covered topics from tuberculosis to tropical agriculture in his three years of reporting. "We only hear of scientific research carried out in Africa from the Western media, because the studies are published first in the West."

Science journalists like Buma Gana face similar difficulties throughout the developing world, yet there is no shortage of science issues to report on. The H5N1 avian influenza virus is rampaging through southeast Asia and Africa. Malaria and HIV are entrenched. And biodiversity in many of the world's tropical regions is diminishing fast.

\section{Sparse coverage}

Reporters in the developing world face challenges that would keep many of their counterparts in the West from even trying. They are often untrained in both science and journalism, lack support and resources, and have an uneasy relationship with the scientists and officials on whom they rely for news and comment. "If science were given a conspicuous place in the media," argues Buma Gana, "much awareness would be created and policy could change on many issues."

A spate of recent initiatives aims to bridge

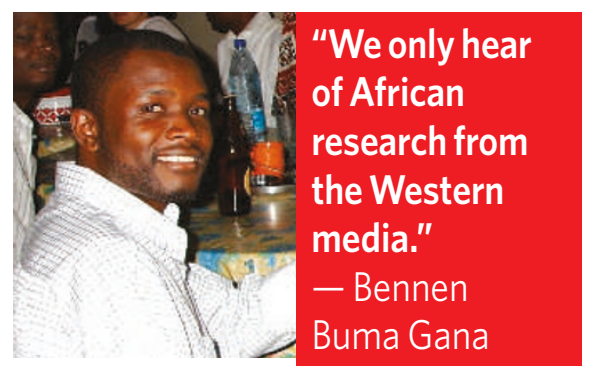

the gap between science and society in the developing world (see 'Spreading the word'). Buma Gana is participating in one, Science for Life (SciLife), which launched in Cameroon in April. This organization hopes to improve the quality of local science journalism by encouraging reporters and researchers to meet and work together. It plans to run seminars, training sessions and field trips to keep journalists aware of scientific developments in both Africa and the West. While it looks for an outside donor, SciLife is relying on contributions from its members -22 so far - to fund activities such as 'science cafés', at which the public can meet scientists and listen to talks on topics such as malaria and bird flu.

Sometimes reporters have to begin their battle in the newsroom itself, where editors are reluctant to run stories on science topics. "Science is still not on the media agenda here," says Colombian freelance journalist Lisbeth Fog. "Convincing the editor that your stories are interesting or at least easy to 'sell' is hard." When Colombian newspapers do cover science, Fog says, it is usually to report - often sensationally - on oddities such as strange animals or on controversial international issues such as genetically modified crops or cloning. "Local science rarely reaches the media," she says.

That silence is sometimes maintained even when the science involves critically important local issues. In July, the International Federation of Journalists released a study on media reporting of HIV and AIDS in some of the countries most affected by the epidemic. Coverage in South Africa was "minuscule" and in India "infrequent", the study found. In Cambodia, even in the two weeks surrounding World AIDS Day in 2005, reporting on HIV 


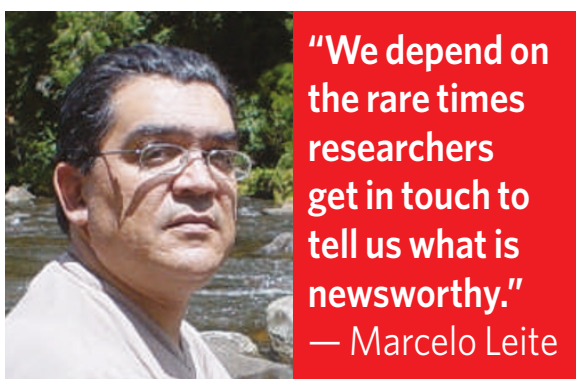

and AIDS occupied just 3\% of the news.

Major media outlets in the West often have dedicated science editors, but in many developing countries there are few. It is not unknown for editors whose usual beats are sports, politics or entertainment to rework science stories out of recognition and into inaccuracy, without consulting the reporter. "There are times where you read your story the following day and just shake your head with anger at the distortion," says Ochieng' Ogodo, a freelance reporter in Nairobi, Kenya.

\section{Secrets and mistrust}

Finding news to report in the first place is challenging enough, he says, because few scientists understand the need to communicate their findings to the public. The stiff bureaucracy at most research institutions doesn't help, he adds: "It can take as long as two months to get a piece of information that should have taken just minutes to supply."

Brazilian science journalist Luisa Massarani agrees. "Trying to find good stories in Brazil or any other Latin American country sometimes feels like being in a black hole, especially when you are young and don't yet have your own contacts." Freelance science writer Marcelo Leite says this is because few Brazilian research centres have press offices that publicize their findings by issuing news releases or bringing scientists and journalists together. "We depend a lot on the rare times that researchers themselves get in touch to tell us what is newsworthy," he says.

Part of the problem is that even when scientists are keen to have their views reported on, they aren't sure how the process might play out. "Scientists fear that reporters will modify their comments in an alarmist way that could create

political or professional problems," says Egyptian geneticist and freelance science journalist Wagdy Sawahel. The result, he says, is that few scientists trust reporters.

Yet scientists are usually easier to deal with as sources than government officials, who "treat all information as a military secret", says Sawahel. "This way of thinking makes it extremely difficult to get hold of the facts about science initiatives, policies or strategic research plans."

Even in China, whose leaders regularly stress the importance of popularizing science, reporting can be difficult. Because government officials decide science policies and allocate funding mainly behind closed doors, scientists rarely feel the need to deal with the media, says Jia Hepeng, a Chinese freelancer based in Beijing. For instance, journalists were strictly forbidden from attending the World Congress of Bioethics in Beijing in August, at which policymakers and scientists were present.

When science becomes politicized, reporting becomes even tougher. Journalists who cover HIV in South Africa, which has one of the highest prevalences of the disease in the world, sometimes receive threatening phone calls from people who believe the HIV virus does not cause AIDS. The AIDS 'dissidents' have tacit - and in some cases open - approval from senior government figures including health minister Manto TshabalalaMsimang, who has endorsed the use of vitamin pills, lemon juice, garlic and olive oil over antiretroviral drugs. An organization that favours vitamin supplements to treat HIV recently threatened to sue South African newspapers and an online news agency for critical reporting. "This has polarized newsrooms and diminished journalists' ability to report accurately," says one South African reporter, speaking anonymously.

Another source of potential controversy is the coverage of genetically modified (GM) crops, particularly in countries - such as Zambia and Zimbabwe - that have banned imports of GM grain as food aid during famines. "There are very few instances where the independent media reports on the latest developments in GM crops," says Talent Ngwande, a freelance journalist based in Zambia's capital Lusaka. A

\section{Spreading the word}

Initiatives are arising to offer support to science journalists in the developing world.

2003: Arab science journalists set up an online discussion group to promote a scientific culture in their region. Six months later, the group forms the Arab Association of Science Journalists, now with more than 100 members.
2004: The Coalition of Journalists on Environment and Agriculture is set up in Malawi. It has organized journalistic training on environmental issues and is encouraging schools to set up science clubs.

2005: The ResearchSEA website is set up to connect research centres and journalists in southeast Asia by publishing press releases and news. Other unrelated initiatives are launched, including the Africa Water Journalists Network, the African Federation of Science Journalists, the Costa Rican Association of Science Journalism and the Science Communicators Association of Nigeria.
2005 study by the UK-based Panos Institute concluded that reporting on GM crops in Brazil, India, Kenya and Zambia tended to follow the government line, whether pro- or anti-GM, and lacked a critical approach.

\section{Long-term training}

Training journalists may help. A few fortunate reporters attend international science journalism workshops each year, but those are usually one-time events. Some argue that governmental support is needed for science communication. "No university here offers science journalism courses," says Pakistani science journalist Aleem Ahmed. He, like some, has launched into science journalism on his own, creating a monthly Urdu-language magazine called Global Science that has published 100 issues over the past eight years.

To improve the lot of working journalists, the World Federation of Science Journalists is about to launch a peer-to-peer training programme. It will match 60 journalists in Africa and the Middle East with one of 16 experienced journalists, either in the same region or in the West, who will act as mentors for two years.

Many believe this could make a difference. "What makes me hopeful about this pro-

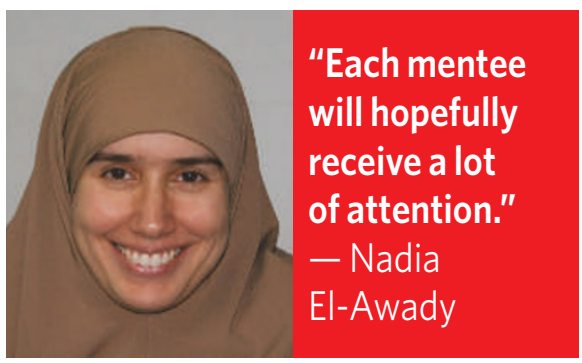

gramme is, firstly, that it is long-term," says Nadia El-Awady, an Egyptian journalist and managing science editor of IslamOnline.net. "Secondly, since each mentor is responsible for only four journalists, each mentee will hopefully receive a good deal of attention."

The programme, funded by Canada's International Development Research Center and the UK Department for International Development, is due to start this month. In November, the mentees are likely to meet with their mentors face-to-face in Nairobi while reporting on the UN Framework Convention on Climate Change.

The scheme will also twin established associations of science writers with fledgling organizations in the developing world, such as the Arab Association of Science Journalists and SciLife. Buma Gana thinks that SciLife will benefit from the scheme and, in return, bring real benefit back to society. "Talking about science from a more African point of view," he says hopefully, "could encourage our governments to invest more in scientific research." Mike Shanahan, a journalist based in London, is news editor at SciDev.Net. The reporters interviewed are all freelance contributors to the site. 